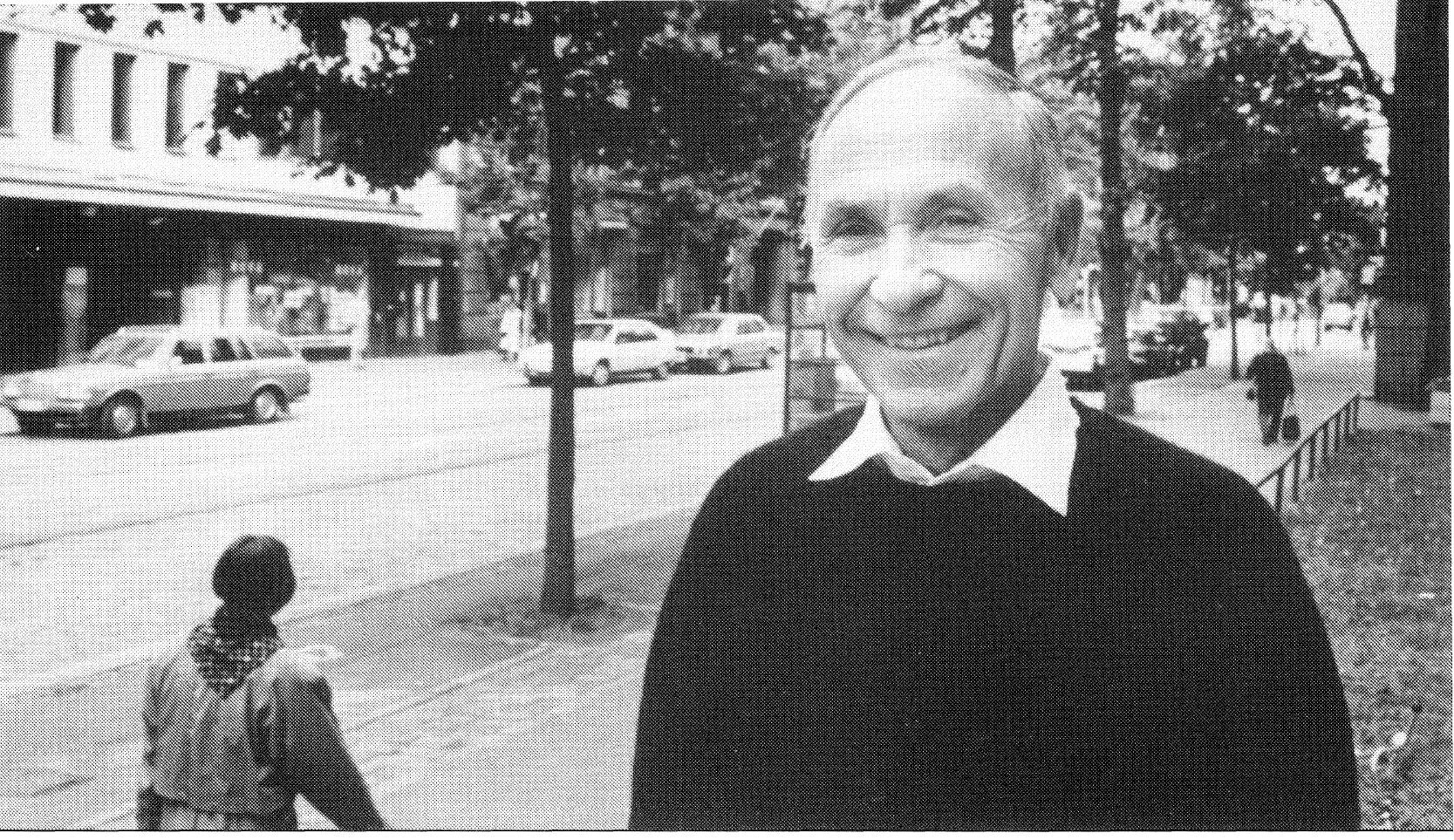

Professori Jack Mezirow luennoi Helsingin yliopistossa syyskuussa. Kuva Porthanian edestä.

\title{
LEENA AHTEENMÄKI-PELKONEN
}

\section{JACK MEZIROW - KRIITTISEN TEORIAN KEHITTÄJÄ}

Aikuisen rajuja muutosprosseja provosoiva radikaali? Knowlesin kesyn andragogiikan vaihtoehdoksi asettuva keulakuva? Habermasia amerikkalaistanut puolifilosofi? Oppimisen salaisuuden nöyrä tutkija? Kuka on Jack Mezirow?

Jack Mezirow vieraili maassamme syyskuussa Helsingin yliopiston rehtorin kutsumana. Hän piti 9. syyskuuta vierailuluennon aiheesta A Transformation Theory of Adult Learning. Virallisen ohjelmansa ohella Mezirow ohjasi useita jatkoopiskelijoita, joiden tutkimusaiheet liittyvät tavalla tai toisella hänen näkemyksiinsä.

Leena Ahteenmäki-Pellkonen kertoo seuraavassa Mezirowin ajattelusta heidän yhteisten keskustelujensa ja Mezirowin teosten pohjalta.
Yhdysvaltalainen professori Jack Mezirow on tehnyt elämäntyönsä jatkuvan koulutuksen ja aikuiskoulutuksen professorina Columbian yliopiston Teachers College -oppilaitoksessa New Yorkissa. Hän on avartanut näkemyksiään myös työskentelemällä eri maissa, lähinnä kolmannessa maailmassa, ja erilaisissa viitekehyksissä, kuten koulutuksellisesti suuntautuneessa terapiassa.

Mezirow on luonut kriittistä teoriaa aikuisten oppimisesta ja koulutuksesta. Useimmat meistä ovatkin lukeneet hänen artikkelinsa " $A$ critical theory of adult learning and education", joka on julkaistu vuonna 1981 yhdysvaltalaisessa Adult Education -lehdessä. Muutamia vuosia sitten Mezirow toimitti kirjan "Fostering critical reflection" (1990) ja julkaisi ensimmäisen itsenäisen teoksensa "Transformative dimensions of adult learning" (1991). 


\section{Teorian rakennuspuita}

Mezirowin historia aikuisten oppimista ja koulutusta koskevan kriittisen teorian kehittäjänä alkoi hänen tutustuessaan lähemmin keskiikäisiin naisiin! Oman Edee-vaimon paluu opiskelemaan keski-ikäisenä aiheutti erinäisiä muutospaineita koko perheen dynamiikkaan. Aikuiskouluttajana työskennellyt Jack kiinnostui kotiovella tapahtuneesta muutoksesta, alkoi ohjata naisten tiedostamisryhmiä ja toimia opintoihinsa palaavien aikuisten ohjaajana. Tämän vaikuttavan ajan jälkikaikuna Mezirowin korostaa voimakkaasti aikuisten muutoksia. Aikuisten muutos- ja oppimisprosesseista avautuu yhä uusia näkökulmia, ja ne kiehtovat häntä jatkuvasti.

Mezirow mainitsee aikaisemmista aikuiskoulutuksen ja sen teorian kehittäjistä erityisesti kaksi suomalaisillekin hyvin tuttua hahmoa. Mezirow on perehtynyt aikuiskoulutukseen 1950ja 1960-luvuilla ensisijaisesti Knowlesin, 1960ja 1970-luvuilla taas Freiren teosten välityksellä. Molempien ajattelutavat olivat hänen mielestään omalla tavallaan kapeita. Knowlesin näkemys rajautuu Mezirowin mukaan lähes yksinomaan konkreettisen opiskeluprosessin suunnitteluun, toteuttamiseen ja arviointiin. Freire taas painottaa liiankin voimakkaasti sosiaalisen toiminnan merkitystä, jolloin opiskelijat nähdään yksinomaan yhteiskunnan jäseninä ja koulutuksesta tulee väline sosiaalisten uudistusten toteuttamiseen.

Mezirow on pyrkinyt yhdistämään nämä näkökohdat ja täydentämään niitä omalla panoksellaan. Mezirow on halunnut avartaa Knowlesin koulutuskeskeistä maailmaa ja osoittaa Freirelle, ettei sosiaalinen toiminta ole koulutuksen välttämätön seuraus. Se on toki mahdollista, mutta toiminta ei saa seurata koulutusta automaattisesti, vaan toiminnan mielekkyys on harkittava tarkkaan ja tilannekohtaisesti.

Mezirow on siis saanut virikkeitä kummankin em. aikuiskouluttajan ajattelusta; sen sijaan hän ei ole koskaan kirjoittanut omia käsityksiäni vastineeksi, saati sitten vastakohdaksi näille aikaisemmille kirjoittajille. Mezirow kokee oman ajattelunsa eroavan esimerkiksi Knowlesin nä- kemyksistä siinä määrin, että ne eivät edes puhu samaa kieltä. Tällöin vertaaminenkin on epätarkoituksenmukaista.

Mezirow on saanut merkittäviä vaikutteita erityisesti oppimisteoriaansa saksalaiselta filosofi ja sosiologi Jürgen Habermasilta. Kuuntelemalla Habermasin luentoja ja lukemalla hänen kirjojensa käännöksiä Mezirow löysi kiinnekohtia omalle ajattelulleen, joka tuntui putoavan koulutuskeskeisen (Knowles) ja yhteiskunnallisesti uudistavan (Freire) ajattelun välimaastoon. Habermasin käsitys tiedonintresseistä, samoin hänen kommunikatiivinen teoriansa ovat auttaneet Mezirowia monen vuoden ajan hahmottamaan ja selkiinnyttämään omaa teoriaansa.

\section{Oppiva ja muuttuva aikuinen}

Aikaisemmin, esimerkiksi vuonna 1981 julkaistussa artikkelissa Mezirow jaotteli oppimisen kolmeen muotoon Habermasin määrittelemien tiedonintressien perusteella. Instrumentaalisessa oppimisessa pyritään lisäämään valmiuksia ja toimimaan entistä tehokkaammin. Tavoitteena on kontrolloida ja hallita ympäristöä. Dialogisessa oppimisessa analysoidaan vuorovaikutusta ja sitä ohjaavia normeja. Emansipatorisessa eli itsereflektoivassa oppimisessa aikuinen tiedostaa omaa toimintaansa ohjaavat tekijät ja niiden syyt ja samalla vapautuu niiden vallasta.

Myöhemmässä vaiheessa, erityisesti viime vuosina julkaistuissa teksteissä, Mezirow painottaa eniten transformatiivista oppimista, joka muuttaa aikuisen aikaisempaa merkitysperspektiiviä Mezirow käyttää merkitysperspektiivitermiä yksilön henkilökohtaisesta viitekehyksestä tai paradigmasta, jonka avulla hän tulkitsee elämäänsä ja suhdettaan ympäristöön. Merkitysperspektiivi rajaa ja valikoi samalla kokemuksia ja vaikuttaa niiden tulkintaan. Merkitysperspektiivin vaikutus ilmenee sitten yksittäisissä merkitysskeemoissa, jotka kohdistuvat elämän eri alueille.

Merkitysperspektiiviin ja -skeemoihin suhteutettuna oppiminen voi tapahtua useilla eri tavoilla. Mezirow ei halua nimittää niitä vaiheiksi, koska hänen oppimisteoriansa ei ole normatiivinen vaiheteoria. Kuitenkin oppimisessa voidaan erottaa seuraavat, erilaajuiset alueet: 
- oppiminen merkitysskeeman puitteissa: tiedon lisääminen ja tehostaminen tietyllä alueella,

- uuden merkitysskeeman oppiminen, esim. uuden kirjan sisältämien näkökulmien omaksuminen,

- yksittäisen merkitysskeeman muutos, esim. uusi suhtautumistapa tiettyyn ilmiöön sekä

- koko merkitysperspektiivin muutos laaja-alaisissa elämänmuutoksissa, jotka järisyttävät aikaisemman merkitysperspektiivin perusteita.

Oppimisen lajit ovat jossain määrin sidoksissa oppijan ikään. Vasta aikuisella on kyky tarkastella omaa elämänkokemustaan ja sen tulkintaperusteita kriittisesti ja reflektoiden. Tämä taas on edellytyksenä merkitysperspektiivin muutokselle.

Aikuisten oppimista voi tarkastella monesta näkökulmasta. Mezirowin käsitys oppimisesta on jatkuvasti muutosprosessissa ja hän oppii jatkuvasti uutta oppimisesta! Tällä hetkellä Mezirowia kiinnostaa erityisesti "propositional learning", joka tapahtuu ilman sanoja erilaisissa vuorovaikutussuhteissa, esimerkiksi lapsen ja aikuisen tai eläimen ja ihmisen välillä. Tässä oppimisen muodossa on yhtymäkohtia Mezirowin käsityksiin erityisesti dialogisesta oppimisesta sen non-verbaalisissa muodossa. Tätä aluetta Mezirow on kuitenkin vasta vähitellen valtaamassa.

\section{Itseohjattu oppiminen?}

Opiskelijan itseohjattu oppiminen tai itseohjautuvuus esitetään varsin usein aikuiskoulutuksen omaleimaisena tavoitteena ja tunnuspiirteenä. Vaikka Mezirowkin on hahmotellut kriittistä teoriaa itseohjatusta oppimisesta ainakin yhden artikkelin verran (1985), hän tänä päivänä välttäisi mieluiten koko termiä. Väistely on ymmärrettävää: Mezirowin teoria on saanut niin paljon kritiikkiä yksilökeskeisyydestään, ettei hän enää halua korostaa sitä termien valinnalla.
Aikuisen itseohjautuvuus merkitsee yksinkertaisesti sitä, että hän on tehokas oppija! Mitä sitten on tehokas oppiminen? Tehokkaalla eli itseohjautuvalla oppijalla on kolme ominaisuutta: hän on kriittisesti reflektoiva, osallistuu arvioivaan diskurssiin ja reflektoituun toimintaan.

Mezirowin käsitys itseohjautuvuudesta on analysoijan silmin varsin kokonaisvaltainen ja epätarkka. Toisaalta itseohjautuvuus samastetaan kaikkiin teorian ihanteisiin. Itseohjautuvuudeksi kutsutaan esimerkiksi kypsää aikuisuutta, tehokasta oppimista tai koulutuksen korkeinta eettistä hyvää.

\section{Aikuiskoulutuksen tehtävät}

Aikuiskoulutuksen ydin on Mezirowille kriittisen reflektion edistäminen. Jos tämä tavoite ei ole mukana koulutuksessa, ei ole kysymys aikuiskoulutuksesta, vaikka opiskelijat olisivat iältään aikuisia ja vaikka heissä tapahtuisi oppimista. Näyttää siltä, että tämän jyrkän jaottelun perusteella suuri osa suomalaista aikuiskoulutusta jouduttaisiin sijoittamaan johonkin toiseen kategoriaan. Mihin sitten? 
Mezirow tekee selvän eron käsitteiden "higher education" ja "adult education" välillä. "Higher education" -kategoriaan kuuluu esimerkiksi erilaisten oppiaineiden (fysiikka, luku- ja kirjoitustaito) opettaminen aikuisille. Tällöin pyritään ensisijaisesti oppisisällön omaksumiseen, ei kriittisen reflektion syntyyn. Silloin kun tavoitteena on kriittisen reflektion edistäminen, on kyseessä varsinainen "adult education".

Sinänsä on positiivista, että aikuiskoulutuksen teorian kehittäjä ottaa kerrankin huomioon oppisisällön merkityksen oppimiselle ja koulutukselle! Mezirowin jaottelu antaa kuitenkin jälleen aihetta kriittisesti arvioivaan diskurssiin: Onko jaottelu mielekäs - opettihan Freirekin sekä kirjallista että poliittista luku- ja kirjoitustaitoa samanaikaisesti? Miten arvioidaan eri oppisisältöjen soveltuvuus kriittisen reflektion perusteeksi? Ja ennen kaikkea: millä perusteilla kriittinen reflektio on nostettu aikuiskoulutusta hallitsevaksi näkökulmaksi?

Sillä, miten Mezirow ymmärtää aikuiskoulutuksen tehtävät, on seurausvaikutuksia myös aikuiskoulutuksen toteutuksen kannalta. Vaikka Mezirowin varhaisimpien tekstien käytännönläheinen ote vaihtuukin haluun kehittää nimenomaan kriittistä teoriaa, hänen käsityksistään voidaan tehdä kuitenkin joitakin, tosin melko yleisiä johtopäätöksiä aikuiskoulutukseen.

Koska aikuiskoulutuksen tehtävänä on Mezirowin mukaan edistää kriittistä reflektiota, koulutuksen tulee mahdollistaa myös kriittinen diskurssi. Se taas ei yleensä toteudu suurissa luentotilanteissa tai esimerkiksi oppimateriaalin välityksellä, vaan vain siellä missä aikuiset voivat arvioida normien totuudellisuutta yhteisesti. Tämä rajaa pois suuren määrän aikuiskoulutuksen toteutusmuotoja - mitä tapahtuu esim. etäopetukselle? Onko mahdollista ymmärtää kriittisen diskurssin toteutumisen ehtoja yhtään laaja-alaisemmin ja monimuotoisemmin?

\section{Arviointia}

Todellisen aikuiskouluttajan ja tutkijan tavoin Mezirow kiirehtii itse arvioimaan teoriansa heikkouksia. Hän mainitsee erityisesti seuraavat:
- oppimisen kontekstisidonnaisuutta ei ole otettu tarpeeksi huomioon

- teoriaa ei ole suhteutettu tarpeeksi toisiin teorioihin; kuitenkin varsinkin sen suhteuttaminen toisiin oppimisteorioihin olisi tärkeää

- esitystapa on melko teoreettista ja vaikeaselkoista; siksi on tärkeää saada palautetta siitä, miten teoria on ymmärretty.

Myös muut tutkijat ovat esittäneet samaa kritiikkiä. Oppimisen konteksisidonnaisuuden unohtaminen näkyy mm. siinä, että Mezirow on kehittänyt teoriansa melko kapean lähtökohdan perusteella, naisliikkeessä ja esimerkiksi kehitysmaissa saamiensa kokemusten perusteella. Niiden yhteisenä nimittäjänä on alistetussa asemassa olleen kasvu kriittiseen tietoisuuteen ja arviointiin. Nämä prosessit ovat merkittävä aikuisten oppimisen muoto, mutta niitä tuskin voidaan pitää ainoina mahdollisuuksina. Jos niihin sisältyvä kriittisen reflektion korostus otetaan aikuiskoulutuksen primaariksi tunnusmerkiksi, aikuiskoulutuksen käsite kapeutuu, kuten edellä on esitetty.

Mezirowin teoria on kieltämättä suhteellisen irrallinen kokonaisuus. Ei niin, etteikö sillä olisi yhteyksiä muihin teoreettisiin ajattelumalleihin - päinvastoin, teoria tuntuu vilisevän viittauksia eri tahoille. On kuitenkin syytä pohtia sitä, miten jäsennetyn kokonaisuuden erilaiset ainekset muodostavat. Vai syntyykö niistä liiankin saumaton kokonaisuus, joka osoittaa, ettei kaikkien lähteiden perusajatuksia ole sittenkään tulkittu oikein? Viimeksi mainittu mahdollisuus nousee selvimmin esiin Habermasin kohdalla.

Mezirowin teorian vaikeaselkoisuus ja myös ihanteellisuus kyllä työllistävät lukijaa. Jo keskeisten käsitteiden runsaus johtaa siihen, että niiden haltuunotto vaatii oman aikansa. Onneksi Mezirow on kuitenkin suhteellisen johdonmukainen: termit tarkoittavat eri teksteissä suunnilleen samaa. Konkreettiset esimerkit puuttuvat varsinkin uusimmista teksteistä, ja käytännön sovelluksia etsivä aikuiskouluttaja joutuu varmasti pettymään. Mezirowin mukaan tietoisuus päämäärästä johtaa melkein itsestään tarkoituksenmukaiseen prosessiin. Mezirow liikkuukin enemmän toimintaperusteiden, ei konkreettisen toiminnan tasolla. 


\section{Pohdittavaa}

Mezirowin ajattelua ei voi kuitenkaan turhentaa tähän sinänsä aiheelliseen kritiikkiin. Puutteistaan huolimatta sen keskellä on oleellisia perusajatuksia, jotka asettavat kysymyksiä myös suomalaiselle aikuiskouluttajalle. Ensinnäkin lähtökohtien mukaisesti Mezirow tuo esiin naisliikkeen yhteydet aikuisen oppimiseen. Tätä aluetta tuskin on tutkittu, vaikka sitä voitaneen pitää yhtenä merkittävänä aikuisten oppimisen kanavana.

Mezirowin näkemys oppimisesta on kaikessa yksilökeskeisyydessäänkin varsin laaja-alainen. Se ei keskity yksinomaan kognitiiviselle ulottuvuudelle, vaan muutos- ja kriisikeskeisen oppimisnäkemyksessä käsitellään myös oppimisen affektiivisia ja sosiaalisia ulottuvuuksia. Oppiminen koskettaa koko ihmistä. Erityisesti oppimiseen liittyvät affektiiviset tekijät ovat jääneet suhteellisen vähälle huomiolle.

Mihin Mezirowin kriittisen teorian kritiikki sitten kohdistuu? Ainakin aikaisempaan aikuiskoulutukseen, joka tukee hänen mukaansa lähinnä instrumentaalista oppimista. On syytä tutkia, mitä tämä väite merkitsee suomalaisessa aikuiskoulutuksessa. Voidaanko olettaa, että se pitää vielä paikkaansa? Mutta jos emme edistä instrumentaalista oppimista, mitä sitten edistämme? Jos emme halua sitoutua emansipatorisen ja transformatiivisen oppimisen päämääriin, mikä sitten on omaleimainen tavoitteemme?

Mezirowin teorian kriittisyys ei kohdistu vallitseviin yhteiskunnallisiin oloihin, eikä Mezirow tarkastele aikuiskoulutuksen tehtäviä yhteiskunnassa, vaan yksilön elämässä. Esim. Freiren edustama yhteiskuntakritiikki on vaimentunut Mezirowilla pehmeämmäksi ja samalla epätäsmällisemmäksi kulttuurikritiikiksi. Kulttuuri ymmärretään yhtenäisenä, eikä alakulttuurien erilaisuutta oteta huomioon.

Nämä varovaiset piirteet kertovat myös siitä, että diskurssin ihannetta ei ole välttämättä helppo saavuttaa. Kuitenkaan sen vaikeus ei oikeuta Mezirowin mukaan luopumaan tästä ihanteesta.
Mezirowin habermasilainen perusajatus siitä, että normeja luodaan rehellisen ja avoimen keskustelun avulla, lienee yksinkertaisuudessaan varsin käyttökelpoinen. Normien sisällön ohella on syytä tutkia erityisesti niiden taustaoletuksia. Voidaan kysyä, mitä tämä periaate merkitsee esimerkiksi aikuiskoulutuksen lähtökohtien ja taustaoletusten suhteen. Mitä otamme annettuina, mitkä ovat meidän kliseemme, joihin uskomme uskovamme, mutta joita emme toteuta? Mitkä ovat kriittisen tutkistelun jälkeenkin aikuiskoulutuksen luovuttamattomia lähtökohtia?

\section{MEZIROWIN TUOTANTOA}

1978. Perspective transformation. Adult Education (USA), Vol. XXVIII, Number 2, 1978, 100-110.

1981 A critical theory of adult learning and education. Adult Education (USA), Vol. 32, Number 1, Fall 1981, 3-24.

1983. A critical theory of adult learning and education. In: Tight, M. (ed.): Education for adults, Volume I: Adult learning and education. London: Croom Helm.

1985a. Aikuiskasvattajien yhteiskunnallinen sitoutuminen. Ensimmäisessä International League for social commitment in adult educationin konferenssissa Ruotsissa heinäkuussa 1985 pidetty esitelmä. Aikuiskasvatus 5, 3, 102-106.

1985b. A critical theory of self-directed learning. In: Brookfield, S. (ed.): Self-directed learning: from theory to practice. New directions for continuing education 25. San Francisco: Jossey-Bass.

1985c. Concept and action in adult education. Adult Education Quarterly. Vol. 35, Number 3, Spring 1985, 142-151.

1990. (ed.). Fostering critical reflection in adulthood. A quide to transformative and emancipatory learning. San Francisco: Jossey-Bass.

1991. Transformative dimensions of adult learning. San Francisco: Jossey-Bass.

1992. Transformation theory: critique and confusion. Adult Education Quarterly Vol. 42, Number 4, Summer 1992, 250-252. 